\title{
Psykiatriens indre konflikter eksponert
}

Siden 2010 har flere brukerorganisasjoner arbeidet for å innføre medisinfrie behandlingstilbud innen psykisk helsevern. Helseminister Høie ga i 2015 de regionale helseforetakene frist til 1. juni 2016 med å etablere et slikt tilbud (1). Det er ikke spesifisert hva tilbudet skal bestå i eller hvem det skal gjelde for, men det vil i praksis rette seg mot pasienter med psykoselidelser og alvorlige stemningslidelser. Pålegget fra ministeren har imidlertid møtt kritikk. I dette nummer av Tidsskriftet beskriver tre psykiatere medisinfrie sykehusposter som «et kunnskapsløst tiltak» (2).

Kan vitenskapshistorien opplyse debatten om medisinfrie tilbud? Den peker på vår kunnskapsforståelses historiske kontekst. Det er frigjørende, fordi det bevisstgjør oss om våre oppfatningers rammer og begrensninger - ikke minst i synet på kunnskap i dagens psykiatri. Galskap ble allerede under opplysningstiden et objekt for medisinen - ikke lenger avvik, men sykdom som legene kunne håndtere (3). Fundamentet for dagens nevrobiologiske sykdomsforståelse ble lagt senere, i det 19. århundre. Den parisiske anatomisk-kliniske modellen man benyttet i somatikken - tanken om at kliniske tegn måtte gjenfinnes $i$ et patoanatomisk substrat - ble da applisert også på psykisk lidelse (4). Faget ble meislet ut etter mønster fra nevrologi og nevropatologi. Samtidig ble psykoanalysen født. Dette var en radikalt annerledes måte å betrakte symptomer og psykisk lidelse på: Symptomene ble forstått som et meningsfullt uttrykk for underliggende konflikter og psykiske spenninger hos pasienten. Om man maler med grov pensel, kan man si at psykiatrien fortsatt står i spenningsfeltet mellom disse to perspektivene.

Til tross for utviklingen innen genetisk og nevrovitenskapelig forskning har vi begrenset kunnskap om årsaker til psykiske lidelser (5). Forskningen har heller ikke resultert i nye former for diagnostikk eller behandling. Det har ført til en fornyet kritikk av hva slags vitenskap psykiatrien er, og hvilken retning faget bør ta (6). Har vi vært så opptatt av biologiske forklaringsmodeller at vi har neglisjert forskning på psykososiale, kontekstuelt fortolkende behandlingsformer for psykiske lidelser (7)? Selv om den biopsykososiale tilnærmingen anerkjennes, står nok den biologiske forståelsesmåten øverst i hierarkiet. Jeg tenker at jo mer utbredt tanken om psykisk lidelse som et naturlig objekt er - for eksempel forstått som kjemisk ubalanse, «noe der inni» hjernen - desto lavere er terskelen for å igangsette medikamentell behandling. Derfor henger kravet om medisinfrie tilbud innen psykiatrien sammen med spørsmålet om vitenskapssyn. Kravet fra brukerne kan ses som uttrykk for at pasientene ikke føler seg hjemme i psykiatriens rådende sykdomsforståelse.

Et argument mot medisinfrie tilbud er manglende kunnskapsgrunnlag. Jeg har kun funnet én randomisert studie om psykoterapi hos umedisinerte pasienter med schizofreni (8). Den viste at kognitiv terapi kan være et godt alternativ for dem som ikke ønsker medisiner. Historien har mange eksempler på utprøvning av effektløse, helseskadelige og dels dødelige terapiformer på psykisk syke, tenk bare på insulinsjokk og lobotomi. At behandling må dokumenteres, er et åpenbart gode. Det er omdiskutert hvor effektive de antipsykotiske midlene er (9), og mange slutter med medisiner på grunn av bivirkninger (10). Samtidig kan antipsykotika ved psykoser redusere dødelighet (11). Kan man da likevel forsvare medisinfrie tilbud?

Samfunnet kan ikke betale for behandling som ikke har effekt. Samtidig er det noe litt passivt over et slikt argument: Kanskje vi burde spørre oss hvorfor det er gjort så få studier på ikke-medikamentelle tiltak ved alvorlig psykisk sykdom? Når de medisinfrie tilbudene nå opprettes, burde dette vært fulgt av en rekke forskningsprosjekter. Vi trenger mer kunnskap om hva som er viktig for pasientene og hvilke undergrupper av pasienter som kan nyttiggjøre seg de forskjellige behandlingsformene.

Grunnleggende sett er dette også et spørsmål om autonomi: Hvem har rett til å bestemme hva som er best i mitt liv? Gitt at pasienten er samtykkekompetent og gir uttrykk for et klart ønske om ikke å bli medisinert, hvorfor skal vi da ikke lytte til det? Er ikke vår viktigste oppgave som leger å formidle kunnskap til pasienten slik at hen selv kan treffe et informert valg? Alternativet, at legen bestemmer, er ikke en farbar vei. Gitt de begrensningene som ligger i dagens kunnskap om årsaker, diagnostikk og terapi, burde pasientpreferanser tillegges stor vekt. De psykisk syke er en gruppe med et særlig svakt rettsvern (12). Det taler for at vi bør lytte.

\section{Litteratur}

1. Brev fra Helse- og omsorgsdepartementet til de regionale helsefortakene. 26.11.2015. Medikamentfri behandling for psykisk syke i alle helseregioner. https://www.regjeringen.no/no/aktuelt/medikamentfri-behandling-for-psykisksyke-i-alle-helseregioner/id2464240/ (13.3.2017)

2. Røssberg JI, Andreassen OA, Ilner SO. Medisinfrie sykehusposter - et kunnskapsløst tiltak. Tidsskr Nor Legeforen 2017; 137: 426-7.

3. Foucault M. Madness and civilization: a history of insanity in the Age of Reason (1965). New York: Vintage Books, 1988.

4. Berrios GE. History and epistemology of psychopathology. I: Kendler KS, Parnas J, red. Philosophical issues in psychiatry III. Oxford: Oxford University Press, 2014.

5. Kendler KS. What psychiatric genetics has taught us about the nature of psychiatric illness and what is left to learn. Mol Psychiatry 2013; 18: 1058-66.

6. Varga S. Naturalism, interpretation, and mental disorder. Oxford: Oxford University Press, 2015: 33-8.

7. Priebe $S$, Burns T, Craig TK. The future of academic psychiatry may be social. Br J Psychiatry 2013; 202: 319-20.

8. Morrison AP, Hutton P, Wardle M et al. Cognitive therapy for people with a schizophrenia spectrum diagnosis not taking antipsychotic medication: an exploratory trial. Psychol Med 2012; 42: 1049-56.

9. Leucht S, Arbter D, Engel RR et al. How effective are second-generation antipsychotic drugs? A meta-analysis of placebo-controlled trials. Mol Psychiatry 2009; 14: 429-47.

10. Lieberman JA, Stroup TS, McEvoy JP et al. Effectiveness of antipsychotic drugs in patients with chronic schizophrenia. N Engl J Med 2005; 353: 1209-23.

11. Tiihonen J, Mittendorfer-Rutz E, Torniainen M et al. Mortality and Cumulative Exposure to Antipsychotics, Antidepressants, and Benzodiazepines in Patients With Schizophrenia: An Observational Follow-Up Study. Am J Psychiatry 2016: 173: $600-6$.

12. Lund K. Tvangsmedisinering må forbys. Tidsskr Nor Legeforen 2017; 137: $263-5$. 